\title{
ANALYSIS OF DEMAND FOR COUNSELLING SERVICES FOR UNIVERSITY / COLLEGE STUDENTS
}

\section{${ }^{\mathrm{a} P E T R}$ ADAMEC, ${ }^{\mathrm{b}}$ DITA JANDERKOVÁ}

Insitute of Lifelong Learning, Mendel University in Brno Zemědělská 5, 61300 Brno, the Czech Republic email: ${ }^{a}$ petr.adamec@mendelu.cz, ${ }^{b}$ dita.janderkova@mendelu.cz

The questionnaire was designed as a part of activities carried out within the OP RDE project "Competitive Graduate of Mendel University in Brno," reg. No. CZ.02.2.69/0.0/0.0/16_015/0002365. Abstract: The offer for counselling services at universities and colleges is nowadays their standard component. University counselling focuses on learning, psychological, social, special-pedagogical and career issues. The aim of the paper is to acquaint with the results of the demand analysis for counselling services among students of all grades of the selected university in the Czech Republic. The results identified specific areas where students would need guidance or their further development (e. g. soft skills) while gender and student preference differences at different stages of study were found for most indicators. The results of such investigations are the core basis for reflection, innovation and improvement of the university counselling services status quo.

Keywords: counselling, issues, services, students, university

\section{Counselling services at universities - general background}

University studies bring about many positive aspects, such as new knowledge, skills, acquired and further developed competences, new social relationships, getting to know new places, gaining autonomy, independence, emotional disengagement from family and many others. On the other hand, university studies also mean a big change in an individual's life. This change is even greater if connected with the change of previous residence place or with the loss of proven and firm contacts and rituals. The young adult (in this context we will mainly be dealing with the 18 to about 35 years old age group) is taking on new roles and associated behavioural patterns. But it is not always possible to fulfil the role of a college student without problems, harmoniously, with no hitches or complications. Some people are more flexible, they can adapt faster, some people need more time, and some people get into trouble. Their psyche is unable to cope with the new challenges, and the first problems, the obstacles and then the symptoms of stress and anxiety appear. But the reason why this happens to only some people is associated with many factors. Examples include personality assumptions, past experience, intellectual capacity, the level of stress resistance, and the like (cf. Allan, McKenna, \& Dominey, 2013).

The counselling services offer at universities and colleges is now their standard component. These services cover several typical and fundamental topics. University counselling focuses on learning, psychological, social or social-legal, specialpedagogical and career-related issues. Counselling services clients are not only dealt with in the form of group activities, courses, seminars but, above all, in the form of individual consultations. Although, the whole academic community (students and academics) can use the counselling services, this paper is mainly aimed at students as counselling services clients.

A young person entering a university comes with a certain image, with a certain expectation. However, the reality tends to be different, and it depends on how much different it actually is. Did they expect more changes, did they have more fears that did not finally come true, or did they underestimate the situation and thought it would be easier? All of this contributes to how the student gradually deals with the problems. Someone needs more time, someone makes more effort, someone corrects their ideas, someone gives up and someone seeks help. For example, others, like more experienced students, friends or family can help, but sometimes even that is not sufficient. And that is when the student has the opportunity to take advantage of the counselling system. In coping with these issues, it also depends on the fact whether the student studies in a full-time or in a combined form of study. These are two quite different groups, and not only the teaching methods but also the counselling services themselves need to be adapted. Slavík et al. (2012) notes that students in the full-time form of study are mostly aged 19-25. They are at the turn of adolescence and early adulthood, and this is accompanied by a certain level of intellectual maturation, certain life and learning experiences, and sometimes also first professional experiences of a practical nature. Combined form students tend to be older than full-time students. The 30-45 age group tends to be the largest, but younger or older people are no exception. Many of them work during their studies and already have a family and children of their own. The implication is that their time and emotional load is enormous. In case they also work in the study field while studying, this needs to be considered by the educators as well, as these students already have a lot of experience, knowledge, and, moreover, a contact with the professional reality, which, with all due respect, even some academics lack. All the above-mentioned aspects can form the basis of future problems that students of both forms of study may have and the university counselling services should be able to address and respond to.

In case a person deals with some issues, whether personal, professional or with their studies, the timing and the way in which they get the appropriate help plays a very important role. There are individuals who prefer face-to-face communication in such cases, but there are also those who prefer to communicate electronically or through social networks, which are becoming a norm in young generation lives. A degree of shyness, uncertainty, a fear of consequences if a person seeks counselling services may also play a significant role. This is why the counselling services centres offer various counselling forms and contacts. Specifically, it is passive counselling (leaflets, information materials or packages either online or printed), individual face-to-face sessions, online chat, e-mail communication, telephone advice, virtual meetings through Skype or group meetings or seminars. A professional counselling services center will not refuse even someone who wants to communicate by, say, a simple letter.

\section{Research focused on counselling services at different levels of schools}

It is very inspiring to get acquainted with the various research results which was conducted at different levels of schools, because the personality of the student and the diagnostics and counselling in the school environment at different stages of personality development are joined vessels. The data collected from these studies then often serve as a fundamental basis for mapping the situation, they are a useful source of knowledge and a basis for many other evaluation processes. Within the Czech Republic, it is possible to find a brief overview of surveys related to counselling issues, for example in the paper Minksová (2010), in which she compiled an overview of major sociological research results conducted from the 1980s to about 2010. Although the information is relatively obsolete and it is not primarily pedagogical-oriented information source, their results can also inspire the school environment. Her overview includes 21 studies among university students, most of whom are longitudinal studies or those that are part of large-scale research projects.

Minksová (2010) points out here not only to those areas where the greatest emphasis is put on university students, but also to those that remain neglected. The first area concentrated on basic information about the students and their background. The second focused on previous and current studies and the circumstances of motivation, study choices and the admission procedure itself. Another topic was questions concerning the student's existential security, i. e. mapping their financial and housing (social) situation. The student's attitudes, opinions, ideas and aspirations were included in another area. The area related to attitudes to university reforms and views 
on equal access to education, issues related to evaluation and the quality of education and study provided was not left out either. The last area focused on the students themselves, on their activities and personality. The summary of these research studies also reveals a plethora of topics in demand in counselling services. Mostly it was an area focused on building soft skills, specifically, for example, communication skills, assertiveness, negotiation skills, coaching and the like.

\subsection{Counselling services at primary and secondary schools}

The effectiveness of counselling for pupils and students can be assessed in a variety of ways. Key indicators may cover a reduction in mental distress, an increase in mental resilience and positive effects on academic success, such as prevention of dropping out of studies and corresponding academic results. Inspiration for the improvement of counselling services can be thus sought not only in the field of higher education counselling services, but also the surveys conducted at primary and secondary schools can be an important incentive as well.

In the USA, for example, they have extensive experience in providing counselling services. This is due to many factors among other things, because the American population is very diverse and is characterized by the large number of nationalities that have found or are looking for a home in this country. Local studies focus on, for example, the work of school counsellors and school counselling programmes and their impact on study outcomes. The common denominator is the support of school counselling services for students in the areas of their academic development and the support of their learning. The area of social and emotional development is not neglected either. All this is to be offered by the counselling system through school counsellors at individual schools.

For example, the results of research conducted by Parzych, Donohue, Gaesser, \& Chiu (2019) in three US states indicated that a higher number of school counsellors correlated with lower student absenteeism, better school performance, higher number of successful graduates, and higher enrolment rate. Based on a nationally representative data set, it was found out that more counselling services provided are significantly reflected in the study results of students and in their graduation results. The authors Goodman-Scott, Sink, Cholewa, Burgess (2018) emphasized the need to extend similar research to other variables related to the broader framework of education referred to as environmental factors.

A summary of six studies focusing on school counselling and learning outcomes (Carey \& Dimmitt, 2012) also yielded other interesting results. It was found out that some school counselling activities produce concrete and measurable results and that not all school counselling activities have the same impact on students. Among other things, the attendance and discipline of students were monitored. The results showed that comprehensive school counselling programmes improve a number of students' learning and behavioural outcomes.

An interesting study by Wilkerson, Perusse, \& Hughes (2013) provided strong evidence that primary schools with comprehensive counselling programmes perform better academically than schools without such counselling programmes. The role of counsellors working in schools in areas with high poverty rate has been followed, for example, by studies by Lapan, Gysbers, Bragg and Pierce (2012). It was found out that there is a positive correlation between a higher number of school counsellors and better school-leaving results, better school attendance and a lower number of disciplinary offenses.

Some studies conducted in the United States have also focused on the successful integration of students with their own or family immigrant history and a language barrier. Examples include studies on the success of students of Latin American descent (Leon, Villares, Brigman, Webb, \& Peluso, 2011). These researchers found out that school counselling designed to be culturally and linguistically appropriate can significantly reduce the gap in outcomes between Latin American students with limited English and other students.

\subsection{Counselling services and the counsellor's personality as a means of social development}

Interesting studies are focused on the student's personality. As mentioned above, the results of the surveys confirmed that school counsellors can help students already in primary school to increase their knowledge of occupations, increase their desire to continue in post-secondary education. It was also found out how students are prepared to study at universities. Counsellors also help pupils and students to learn more about themselves, about possible fields of their further education, individual occupations and the world of work in general. Mostly, these surveys were conducted on samples of students attending schools who participated in projects aimed at increasing the academic success of students (cf. Mariani, Berger, Koerner, Sandlin (2016).

There are differences between the results of individual and group counselling. Surprisingly, the individual counselling was less effective and group counselling interventions proved more effective. Summarizing the results of their study, Whiston and Quinby (2009) found out that school counselling interventions had relatively large effects in solving problems and increasing professional knowledge and academic outcomes, as well as students' academic and personal social outcomes. Last, but not least, the relationship between school counsellors, students, parents and other stakeholders has also been explored (e.g., Kayler \& Sherman, 2009).

Investigations focused on the influence of counselling services on the social-emotional characteristics and development of students' social skills can also be found in the scholarly literature. It was found out that not only the cognitive abilities, but also social and personality characteristics or mental health are responsible for success in education. Specifically, for example, how to improve attitudes to learning, strengthen selfconfidence in relation to the academic results. Attention was also paid to the question of the role played by small social groups. The results showed that small group interventions were more effective than whole-class interventions (Steen, Liu, Shi, Rose, \& Merino, 2018). Studies have not forgotten the role of the family, for example, in relation to managing aggression and attention problems (Amatea, Thompson, Rankin-Clemons, \& Ettinger, 2010). It has also been found that counselling intervention in students can play a positive role in the early identification and prevention of depressive symptoms and suicidal thoughts (Erickson \& Abel, 2013).

The effectiveness of counselling interventions is important in an era of evidence-based practices. Examples of evidence-based counselling programmes rooted in humanistic theories can be cited, such as a meta-analysis by Villares, Lemberger, Brigman and Webb (2011), the results of which demonstrate the importance of integrating human capital into school by teaching students' basic educational skills as a counselling and student outcomes.

For some researchers, the person of a school counsellor who works specifically with students with lower social capital was also interesting. For example, high school students who visited their school counsellor for information about the university were found to be more likely to enrol in college, and the increase in the number of high school counsellors in schools alone increased the likelihood that students would enrol in college. The school counsellor also had a positive effect on the reduced incidence of behavioural disorders. Overall, it has been confirmed that a school counsellor is a positive factor that is able to reduce the incidence of behavioural disorders, help students and thus improve their current and especially future careers and employability in the labour market. 


\subsection{Counselling services related to the university environment}

One of the interesting areas is the readiness of students to study at universities and for professional careers. Research studies look, for example, at the influence of counsellors on students' thinking about higher education. The results show that counsellors can play a crucial role, not only providing information through contact, but are able to act as significant influencers of students' thinking in further education (Cholewa, Burkhardt and Hull, 2015). Among other things, student contact with counsellors has been found to affect the number of students enrolled in colleges (Bryan, Moore-Thomas, Day-Vines, Holcomb-McCoy (2011) or Hurwitz, Howell (2014). School counsellors thus play a very important role in the preparation for university studies and especially in its selection.

The presence of comprehensive school counsellors is associated with a number of positive student outcomes - from better attendance to a stronger sense of connection with school and a tendency towards further education, improved learning outcomes, behaviour and mental health. Researchers Watkinson, \& Hersi (2014) sought to find specific characteristics of students seeking professional school counsellors to obtain information about the college. From a methodological point of view, it is worth mentioning that case studies were used. The wide thematic range of this issue is also confirmed by studies carried out with the help of the Delphi method, which examined the role of school counsellors in providing counselling in the field of university readiness for students with autism spectrum disorders (Krell, \& Perusse, 2012).

In general, in the context of the above, it can be stated that students who have access to school counsellors and comprehensive school counselling programmes are more likely to have academic and behavioural success in school. A good example is provided by studies that found out how students using counselling services in high school and whether they then look for them in college. Counselling activities have helped students learn more informed decisions (eg, Lapan, Poynton, Balkin, Jones, 2019). The topic of transition to university and subsequent successful employment is also addressed by other studies, e.g., Lapan, Whitcomb, \& Aleman, 2012; Pham \& Keenan, 2011, Bryan, Holcomb-McCoy, Moore-Thomas, \& Day-Vines, 2009; Militello, Carey, Dimmitt, Lee, \& Schweid, 2009.

The topic of counselling at the university itself is the subject of many studies. For example, McKenzie, Murray \& Richelieu (2015) examined the effectiveness of university counselling for students with academic problems. It has been shown that, although the lives of university students are associated with significant stressors, there is little data on the extent to which clients of student counselling services encounter difficulties related to academic issues and how effective counselling is for them. The aim of this survey was to evaluate the degree of effectiveness, reliability and significance of changes in students with academic problems after using counselling services. The reason for conducting more detailed research in this area was the preliminary research, which found that $92 \%$ of students face some academic problems. At the same time, counselling services were found to lead to reliable changes in $67 \%$ of students who report academic problems. It can therefore be stated that counselling services have led to reliable changes in a high percentage of those who have these difficulties.

\section{Survey methodology}

The Counselling Centre of Mendel University in Brno (hereinafter MENDELU), whose activities are the subject of this article, was established in January 2008 and is part of the Institute of Lifelong Learning of the mentioned university. Counselling services are provided here to students, employees, applicants, graduates and the public. Working with potential future students is very important in terms of their decisionmaking process. If a high school student or a working person decides for a given university, he or she has a more realistic view of what awaits them, thanks to communication with counsellors. The Counselling Centre regularly informs students about its activities, mainly through information e-mails. This non-violent form of mediating information proves itself in the so-called first line, especially at the beginning of the academic year. Of course, applicants with specific needs who have some form of disability or disadvantage will also find help. They will get acquainted with information on considering the specific need in the study, which the university guarantees (for more see, for example, Adamec, Janderková, 2020).

\subsection{Survey objectives and respondents' structure}

The aim of the survey focused on the demand for counselling services was to improve the focus of counselling services of the Counselling Centre according to the current needs of students. The survey was conducted through an online questionnaire and was distributed to the email addresses of public university students. The questionnaire contained 10 questions, but a total of 70 survey features. Due to the use of the quantitative method, the respondents' answers were evaluated using software SPSS for mass data analysis. The free answers of the respondents were categorized. A total of 197 completed questionnaires were worked on. In the following text, the answers are presented in the form of tables, the relative frequencies of individual variants of answers (\%) and the outputs from the classification of the second level are commented, mostly in the form of textual comments on the differences found. At least a $10 \%$ difference between the groups was considered significant.

Tab. 1: Respondents' structure
\begin{tabular}{|l|c|c|c|}
\hline \multirow{2}{*}{ Indicator } & Characteristic & $\begin{array}{c}\text { Absolute } \\
\text { Frequency }\end{array}$ & $\begin{array}{c}\text { Relative } \\
\text { Frequency }\end{array}$ \\
\hline \multirow{2}{*}{ Sex } & Male & 60 & $30.5 \%$ \\
\cline { 2 - 4 } & Female & 137 & $69.5 \%$ \\
\hline \multirow{3}{*}{$\begin{array}{l}\text { Study } \\
\text { Degree }\end{array}$} & Bachelor (B.Sc./B.A.) & 161 & $81.7 \%$ \\
\cline { 2 - 4 } & Follow-up Master (M.Sc.) & 28 & $14.2 \%$ \\
\cline { 2 - 4 } & Doctoral (Ph.D.) & 8 & $4.1 \%$ \\
\hline \multirow{2}{*}{$\begin{array}{l}\text { Study } \\
\text { Form }\end{array}$} & Full-time & 176 & $89.3 \%$ \\
\cline { 2 - 4 } & Combined & 21 & $10.7 \%$ \\
\hline
\end{tabular}

Source: Author's own work.

The aim of the survey was to find answers to the following questions:

1. What is the level of awareness of the existence of the Counselling Center?

2. What difficulties do students most often encounter during their studies?

3. Which areas make their study the most difficult for students?

4. What form of counselling do students prefer for solving their difficulties or personal development?

5. Which area of counselling would students currently want to use for themselves?

6. What information or services would students appreciate for their personal development during their studies?

7. To what extent do students' opinions differ according to gender, degree and form of study?

\section{Survey results}

In the survey introduction, the respondents were asked if they knew about the existence of the MENDELU Counselling Centre (hereinafter PPC). The answers showed that more than fourfifths of respondents know PPC (85.8\%). The level of awareness of existence was compared in relation to selected indicators and the results are shown in the following Table 2. The results of analyses show that the level of awareness increases with the degree, while at the bachelor's degree PPC knows approximately every eighth respondent $(83.9 \%)$, all respondents 
already knew about the existence of PPC at the doctoral study (100\%). The results also show a higher level of awareness among respondents with full-time study compared to the combined form (87.5\% vs. $71.4 \%)$.

Tab. 2: Level of Awareness of the Counselling Centre

\begin{tabular}{|c|c|c|c|}
\hline \multirow{2}{*}{ Indicator } & Characteristic & Yes & No \\
\hline \multirow{2}{*}{ Sex } & & & \\
\cline { 2 - 4 } & Male & $83.3 \%$ & $16.7 \%$ \\
\hline \multirow{3}{*}{ Study Degree } & B.Sc. & $83.9 \%$ & $16.1 \%$ \\
\cline { 2 - 4 } & M.Sc. & $92.9 \%$ & $7.1 \%$ \\
\cline { 2 - 4 } & Ph.D. & $100.0 \%$ & $0.0 \%$ \\
\hline \multirow{2}{*}{ Study Form } & Full-time & $87.5 \%$ & $12.5 \%$ \\
\cline { 2 - 4 } & Combined & $71.4 \%$ & $28.6 \%$ \\
\hline
\end{tabular}

Source: Author's own work.

Subsequently, a set of questions identified the difficulties that respondents encounter during their studies. Respondents were asked to indicate on a scale from "definitely yes" (1) to "definitely no" (4) whether they encountered the problem during their studies.

The results of the analyses show that the most common problem for three quarters of respondents $(74.6 \%)^{1}$ is procrastination (tasks postponement), furthermore, the amount of curriculum (71.0\%) and the comprehensibility of the curriculum (59.9\%). In contrast, respondents are the least likely to encounter learning difficulties associated with their disability (8.1\%).

Tab. 3: What difficulties do you encounter most often during your studies?

\begin{tabular}{|l|c|c|c|c|c|}
\hline & $\begin{array}{c}\text { Definitely } \\
\text { yes }\end{array}$ & $\begin{array}{c}\text { Rather } \\
\text { yes }\end{array}$ & $\begin{array}{c}\text { Rather } \\
\text { no }\end{array}$ & $\begin{array}{c}\text { Definitely } \\
\text { no }\end{array}$ & Average \\
\hline $\begin{array}{l}\text { Procrastination } \\
\text { (tasks } \\
\text { postponement) }\end{array}$ & $41.1 \%$ & $33.5 \%$ & $22.9 \%$ & $2.5 \%$ & 1.87 \\
\hline $\begin{array}{l}\text { Curriculum } \\
\text { amount }\end{array}$ & $28.4 \%$ & $42.6 \%$ & $27.5 \%$ & $1.5 \%$ & 2.02 \\
\hline $\begin{array}{l}\text { Curriculum } \\
\text { comprehensibility }\end{array}$ & $21.8 \%$ & $38.1 \%$ & $37.1 \%$ & $3.0 \%$ & 2.21 \\
\hline $\begin{array}{l}\text { Level of study } \\
\text { difficulty }\end{array}$ & $15.2 \%$ & $44.2 \%$ & $33.0 \%$ & $7.6 \%$ & 2.33 \\
\hline Time management & $19.3 \%$ & $38.1 \%$ & $36.0 \%$ & $6.6 \%$ & 2.30 \\
\hline $\begin{array}{l}\text { Perfectionism, } \\
\text { high performance } \\
\text { pressure }\end{array}$ & $17.3 \%$ & $32.5 \%$ & $41.6 \%$ & $8.6 \%$ & 2.42 \\
\hline $\begin{array}{l}\text { Inappropriate } \\
\text { learning style I } \\
\text { use }\end{array}$ & $14.2 \%$ & $33.5 \%$ & $45.7 \%$ & $6.6 \%$ & 2.45 \\
\hline $\begin{array}{l}\text { Transition from } \\
\text { secondary to high } \\
\text { school }\end{array}$ & $10.7 \%$ & $18.3 \%$ & $39.5 \%$ & $31.5 \%$ & 2.92 \\
\hline $\begin{array}{l}\text { Difficulties to } \\
\text { complete my } \\
\text { studies }\end{array}$ & $6.1 \%$ & $16.2 \%$ & $47.7 \%$ & $30.0 \%$ & 3.02 \\
\hline $\begin{array}{l}\text { Studying does not } \\
\text { make sense to me }\end{array}$ & $8.1 \%$ & $13.7 \%$ & $38.6 \%$ & $39.6 \%$ & 3.10 \\
\hline $\begin{array}{l}\text { Inappropriate } \\
\text { study field choice }\end{array}$ & $7.1 \%$ & $11.2 \%$ & $42.1 \%$ & $39.6 \%$ & 3.14 \\
\hline $\begin{array}{l}\text { Study difficulties } \\
\text { related to my } \\
\text { disability }\end{array}$ & $2.5 \%$ & $5.6 \%$ & $16.2 \%$ & $75.7 \%$ & 3.65 \\
\hline Source Autor & $0 \% 1 \% 0 r k$ & & & \\
\hline
\end{tabular}

Source: Author's own work.

The results are given in detail in Table 3 above. The difficulties in the table are ranked according to the sum of the relative frequencies of the "definitely yes" and "rather yes" variants from the highest to the lowest. The table also includes the average values of answers for individual problems, the lower the value,

\footnotetext{
${ }^{1}$ Proportion of respondents who answered „definitely yes“ or „rather yes“.
}

the more often the respondents stated that they encounter a problem during their study.

The individual difficulties were further compared in relation to selected indicators. The results of the analyses showed that women more often feel the inappropriate choice of field of study $(21.9 \%$ vs. $10.0 \%)$ and men are more faced with the problem of transition from high school to university (36.7\% vs. $25.5 \%$ ). In terms of the degree ${ }^{2}$, bachelor's degree respondents, compared to respondents at the subsequent master's degree, report greater problems with the amount of curriculum (74.5\% vs. $57.1 \%)$ and with procrastination (75.8\% vs. 64.3\%). Respondents from the follow-up master's degree study more often mentioned a problem with an inappropriate learning style as they learn (60.7\% vs. $44.7 \%)$. In terms of the form of study, respondents from full-time study, compared to respondents from the combined form of study, face more problems with the curriculum comprehensibility (61.9\% vs. $42.9 \%)$, with an inappropriate learning style as they learn (48.9\% vs. $38.1 \%)$, with procrastination ( $76.7 \%$ vs. $57.1 \%$ ), with time management (58.5\% vs. $47.6 \%$ ), with inappropriate choice of field of study (19.9\% vs. $4.8 \%)$ and the fact that the study does not make sense to them $(24.4 \%$ vs. $0.0 \%)$.

Using another battery of questions, areas that complicate the study of respondents were identified. Respondents for each area answered on a scale from "definitely yes" (1) to "definitely no" (4). The results of the analyses show that stress complicates the studies to most respondents $(76.7 \%),{ }^{3}$ followed by exhaustion (55.3\%) and decision-making (51.8\%). In contrast, peer relationships (9.7\%) and addictions, eating disorders (alcohol, excessive computer use, etc.) (11.7\%) are the least complicating areas for approximately one tenth of respondents.

The results are presented in detail in the following Table 4. The areas of complications are sorted in the table according to the sum of the relative frequencies of the variants "definitely yes" and "rather yes" from the highest to the lowest. The table also includes the average values of answers for individual areas, the lower the value, the more often the respondents stated that the area complicates their studies.

Individual areas complicating the study were further compared in relation to selected indicators. The results of the analyses showed that women, more often than men, stated that stress complicates their studies (82.5\% vs. 63.3\%), furthermore, anxiety, depression (48.9\% vs. $30.0 \%)$, exhaustion (61.3\% vs. $41.7 \%)$, psychosomatic difficulties $(25.5 \%$ vs. $13.3 \%)$, emotional problems (40.1\% vs. $15.0 \%)$ and decision-making (56.9\% vs. $40.0 \%)$. In terms of the degree of study ${ }^{4}$, bachelor's respondents, in comparison with respondents at the subsequent master's degree, state that exhaustion $(57.1 \%$ vs. $39.3 \%)$ and decision-making (55.3\% vs. 32.1\%) complicate their studies more. In terms of the form of study, respondents from full-time study, compared to respondents from the combined form of studies, state that their studies is more complicated by relationships with teaching authorities (19.3\% vs. $0.0 \%)$, stress (78.4\% vs. $61,9 \%)$ and lack of funding (22.7\% vs. $9.5 \%)$. In contrast, respondents from the combined study more often mentioned family relationships (38.1\% vs. $17.6 \%$ ), partnerships (33.3\% vs. $18.2 \%)$ and challenging life circumstances $(28.6 \%$ Vs. $17,0 \%)$.

Tab. 4: Which of the following areas make your studies the most difficult?

\begin{tabular}{|l|c|c|c|c|c|}
\hline & $\begin{array}{c}\text { Definitely } \\
\text { yes }\end{array}$ & Rather yes & Rather no & $\begin{array}{c}\text { Definitely } \\
\text { no }\end{array}$ & Average \\
\hline Stress & $26.9 \%$ & $49.8 \%$ & $15.2 \%$ & $8.1 \%$ & 2.05 \\
\hline Exhaustion & $14.7 \%$ & $40.6 \%$ & $33.5 \%$ & $11.2 \%$ & 2.41 \\
\hline
\end{tabular}

\footnotetext{
${ }^{2}$ Due to low number of respondents, Ph.D. students were excluded from the analyses. ${ }^{3}$ Proportion of respondents who answered „definitely yes“ or „rather yes“.
}

${ }^{4}$ Proportion of respondents who answered ",definitely yes" or „rather yes". 


\begin{tabular}{|c|c|c|c|c|c|}
\hline \begin{tabular}{|l|}
$\begin{array}{l}\text { Decision- } \\
\text { making }\end{array}$ \\
\end{tabular} & $10.7 \%$ & $41.1 \%$ & $33.0 \%$ & $15.2 \%$ & 2.53 \\
\hline \begin{tabular}{|l} 
Anxiety, \\
depression
\end{tabular} & $11.7 \%$ & $31.5 \%$ & $31.5 \%$ & $25.3 \%$ & 2.71 \\
\hline \begin{tabular}{|l|} 
Low \\
performance, \\
efficiency
\end{tabular} & $9.7 \%$ & $28.9 \%$ & $52.8 \%$ & $8.6 \%$ & 2.60 \\
\hline \begin{tabular}{|l|} 
Emotional \\
problems
\end{tabular} & $9.1 \%$ & $23.4 \%$ & $35.0 \%$ & $32.5 \%$ & 2.91 \\
\hline $\begin{array}{l}\text { Communicati } \\
\text { on difficulties }\end{array}$ & $10.7 \%$ & $21.3 \%$ & $55.8 \%$ & $12.2 \%$ & 2.70 \\
\hline \begin{tabular}{|l|}
$\begin{array}{l}\text { Psychosomati } \\
\text { c difficulties }\end{array}$ \\
\end{tabular} & $7.6 \%$ & $14.3 \%$ & $42.1 \%$ & $36.0 \%$ & 3.07 \\
\hline Lack of funds & $8.6 \%$ & $12.7 \%$ & $41.1 \%$ & $37.6 \%$ & 3.08 \\
\hline \begin{tabular}{|l|}
$\begin{array}{l}\text { Family } \\
\text { relationships }\end{array}$ \\
\end{tabular} & $6.6 \%$ & $13.2 \%$ & $29.9 \%$ & $50.3 \%$ & 3.24 \\
\hline Partnerships & $5.6 \%$ & $14.2 \%$ & $32.0 \%$ & $48.2 \%$ & 3.23 \\
\hline $\begin{array}{l}\text { Challenging } \\
\text { and traumatic } \\
\text { life } \\
\text { circumstances } \\
\end{array}$ & $7.1 \%$ & $11.2 \%$ & $32.5 \%$ & $49.2 \%$ & 3.24 \\
\hline $\begin{array}{l}\text { Relations } \\
\text { with } \\
\text { authorities } \\
\text { (teachers) } \\
\end{array}$ & $4.6 \%$ & $12.7 \%$ & $46.2 \%$ & $36.5 \%$ & 3.15 \\
\hline \begin{tabular}{|l|} 
Addictions, \\
eating \\
disorders \\
\end{tabular} & $1.5 \%$ & $10.2 \%$ & $24.9 \%$ & $63.4 \%$ & 3.50 \\
\hline \begin{tabular}{|l} 
Peer \\
relationships
\end{tabular} & $3.6 \%$ & $6.1 \%$ & $35.0 \%$ & $55.3 \%$ & 3.42 \\
\hline
\end{tabular}

Source: Author's own work.

Subsequently, respondents were to indicate what form of counselling they prefer or would prefer for solving their problems or for their personal development (Table 5). A total of seven forms of counselling were on offer and respondents had to choose a maximum of three options. The answers of those respondents who indicated more options were excluded from the analyses. Most often, respondents prefer or would prefer individual consultations (81.6\%). More than half of the respondents $(54.7 \%)$ mentioned group meetings / seminars and a quarter of respondents (25.3\%) prefer the e-mail form of counselling. Skype is the least suitable for respondents (5.3\%).

Tab. 5: What form of counselling do you prefer or would prefer for solving your problems or for your personal development?

\begin{tabular}{|l|c|}
\hline & Direction \\
\hline Individual consultations (face-to-face) & $81.6 \%$ \\
\hline Group meetings / seminars & $54.7 \%$ \\
\hline E-mail & $25.3 \%$ \\
\hline $\begin{array}{l}\text { Passive counselling (online or printed } \\
\text { information materials) }\end{array}$ & $19.5 \%$ \\
\hline On-line chat & $17.9 \%$ \\
\hline Telephone counselling & $7.4 \%$ \\
\hline Skype & $5.3 \%$ \\
\hline
\end{tabular}

Source: Author's own work.

The preferred form of counselling was further compared in relation to selected indicators. The results of the analyses showed that men prefer more individual consultations than women (89.5\% vs. $78.2 \%)$, while women prefer group meetings/ seminars more than men ( $57.9 \%$ vs. $47.4 \%$ ). In terms of the form of study, respondents from the combined study prefer e-mail more than respondents from the full-time form of study $(36.8 \%$ vs. $24.0 \%$ ). On the other hand, they prefer group meetings / seminars $(56.7 \% \text { vs. } 36.8 \%)^{5}$.

\footnotetext{
${ }^{5}$ In case of study form we point out to low frequencies; the results can be considered as indicative only.
}

At the end of the questionnaire, areas of counselling were identified that the respondents would like to use for themselves or which they currently use. The results show that more than half of the respondents (53.8\%) would like to use or already use career counselling (assurance of the chosen field, choice of follow-up studies, career building) and almost the same number of respondents (48.7\%) would like to use, has already used or is using seminars, courses, workshops. Furthermore, the respondents mentioned study counselling (solving problems with the organization of the curriculum, inappropriate learning style) (34.0\%) and psychological counselling (mental difficulties, relationship issues, self-confidence, emotional difficulties, coping with disability, trauma, childhood situation, search for own identity, etc.) (26.9\%). The results are documented in detail in the following Table 6.

Tab. 6: Identification of the counselling areas currently being used or would be used by the respondents

\begin{tabular}{|l|c|}
\hline & Share \\
\hline Career counselling & $53.8 \%$ \\
\hline Seminars, courses, workshops & $48.7 \%$ \\
\hline Study counselling & $34.0 \%$ \\
\hline Psychological counselling / advice & $26.9 \%$ \\
\hline Coaching & $24.4 \%$ \\
\hline Personality diagnostics & $23.9 \%$ \\
\hline Nutrition counselling & $21.8 \%$ \\
\hline Social and legal counselling & $10.2 \%$ \\
\hline Support for students with specific needs & $4.6 \%$ \\
\hline Addictology counselling, addictions & $3.6 \%$ \\
\hline
\end{tabular}

Source: Author's own work.

Subsequently, the required areas of counselling were compared in relation to selected indicators. The results of the analyses showed that women are more interested than men in career counselling (65.0\% vs. 52.8\%), in seminars, courses, workshops $(60.0 \%$ vs. $45.3 \%)$ and in psychological counselling (34.2\% vs. $22.6 \%)$. In terms of the degree of study ${ }^{6}$, bachelor's respondents are more interested in study counselling (difficulties in organizing the curriculum, inappropriate learning style, etc.) (42.0\% vs. $26.1 \%)$, in nutritional counselling ( $25.9 \%$ vs. $13.0 \%$ ). Respondents from the follow-up master's degree are more interested in career counselling ( $82.6 \%$ vs. $57.3 \%)$. In terms of the form of study, respondents from combined study are more interested in seminars, courses, workshops (68.4\% vs. 53.9\%) and coaching ( $36.8 \%$ vs. $26.6 \%$ ) compared to respondents from the full-time form of study). In contrast, full-time respondents are more interested in career counselling (66.2\% vs. $21.1 \%$ ), study counselling $(40.3 \%$ vs. $26.3 \%)$ and psychological counselling (31.8\% vs. $21.1 \%)^{7}$.

Only half of the respondents (52.3\%) answered the question "What topics of workshops, seminars and personal development courses would be of interest to you?" It was a free question, i.e., without the offered variants of answers. The individual responses were categorized and the categories of responses, including relative frequencies, are documented in the following Table 7.

Tab. 7: Topics of workshops, seminars and personal development courses of interest

\begin{tabular}{|l|c|}
\hline Suggested workshops topics & $\begin{array}{c}\text { Relative } \\
\text { Frequencies }\end{array}$ \\
\hline $\begin{array}{l}\text { Communication and presentation skills, body } \\
\text { language }\end{array}$ & $20.2 \%$ \\
\hline Procrastination, time management & $20.2 \%$ \\
\hline
\end{tabular}

${ }^{6}$ Due to low number of respondents, Ph.D. students were excluded from the analyses. ${ }^{7}$ Due to low number of respondents, Ph.D. students were excluded from the analyses. 


\begin{tabular}{|l|c|}
\hline $\begin{array}{l}\text { Stress, fear and tremor / stage fright management } \\
\text { and self-confidence }\end{array}$ & $17.2 \%$ \\
\hline CVs or cover letters writing, interview preparations & $16.2 \%$ \\
\hline Entrepreneurship & $14.1 \%$ \\
\hline $\begin{array}{l}\text { Future employment counselling - job opportunities } \\
\text { in the field, where to look for a job, how to enter } \\
\text { the labour market, company, lectures etc. }\end{array}$ & $9.1 \%$ \\
\hline Learning effectivity & $8.1 \%$ \\
\hline Meditation, peace of mind & $7.1 \%$ \\
\hline Professional papers / theses writing & $7.1 \%$ \\
\hline Personality diagnostics, self-knowledge & $6.1 \%$ \\
\hline Motivation & $5.1 \%$ \\
\hline Foreign languages, mostly English & $5.1 \%$ \\
\hline Microsoft Office, SAP courses & $5.1 \%$ \\
\hline Relationships & $4.0 \%$ \\
\hline Healthy lifestyle & $4.0 \%$ \\
\hline Others & $36.3 \%$ \\
\hline
\end{tabular}

Source: Author's own work.

Some respondents mentioned more than one topic, so the sum of relative frequencies in the table is higher than $100 \%$. The results show that one fifth of respondents (20.2\%) are most interested in workshops, seminars and courses focusing on communication, presentation skills and body language, and for an equally large group (20.2\%) on topics of procrastination and time management. Respondents are also interested in the areas of coping with stress, fear, fear and self-confidence (17.2\%), writing CVs and cover letters and preparing for an interview (16.2\%) and the topic of entrepreneurship (14.1\%).

\section{Summary and conclusion}

Quality counselling must be based on the potential users of the counselling services themselves. Certainly, it would be a mistake to go the other way, when the range of services is planned by the consulting institution, and it is expected that clients will find themselves in it in some way or that they will "fit" into it. The evaluation process is the basis of the quality work of any institution. And for institutions working with human resources, simply with people (students, teachers, counsellors), this is one of the key priorities. Therefore, a questionnaire survey was conducted, the results of which are also part of this paper. After the evaluation, the data that was expected also appeared, but also even that which serves as a stimulus for reflection and possible changes.

Counselling is an important area that belongs to the activities of universities. Previously, this activity was on the fringes of interest, but the situation is changing in line with how the social atmosphere and view of a person's personality is changing - in our case, the student's. They have begun to be perceived in their integrity. The student is far from solving only the study issues, although it should be their fundamental and crucial activity. Only an individual as an integrated personality can adequately devote themselves to study and deliver quality results. It follows that the counselling services provided are not only in the interests of the students themselves, but also of the entire university and, ultimately, of society. The counselling activity carried out by individual higher education institutions is an indicator of the quality of the given institution and its results become the basis for its evaluation.

Today, we focus too much on the professional side of a person's life, we monitor their performance, achievements, career and at the same time we neglect such a fundamental part of life as private life, ways of spending free time. It is not possible to separate completely these two areas; a person with inner peace and mental stability gives better work performance. The world needs not only super-executive works or employees, but it also needs people with emotional experiences, able to support others and support themselves. There are times when the world confronts us with unknown tasks for which we do not have patterns of behaviour, we cannot draw on experience. Then we must rely on ourselves and, if possible, seek help in our surroundings. And it is the Counselling Centre that sees its mission in this area and sees in it the meaning of its operation.

\section{Literature:}

1. Adamec, P., \& Janderková, D. (2020). Evaluace poradenských služeb na veřejné vysoké škole. Diagnostika a poradenství $\checkmark$ pomáhajících profesích, 4(1), 64-80. Praha: PALESTRA. ISSN 2570-7612

2. Allan, J. F., McKenna, J., \& Dominey, S. (2013). Degrees of resilience: profiling psychological resilience and prospective academic achievement in university inductees. British Journal of Guidance \& Counselling, 42(1), 9-25. doi:10.1080/03069885. 2013.793784

3. Amatea, E. S., Thompson, I. A., Rankin-Clemons, L., \& Ettinger, M. L. (2010). Becoming partners: A school-based group intervention for families of young children who are disruptive. Journal of School Counseling, 8(36). Retrieved from http://www.jsc.montana.edu/articles/v8n36.pdf

4. Bryan, J., Moore-Thomas, C., Day-Vines, N. L., \& HolcombMcCoy, C. (2011). School Counselors as Social Capital: The Effects of High School College Counseling on College Application Rates. Journal of Counseling and Development, 89 (2), 190-199. doi: 10.1002/j.1556-6678.2011.tb00077.x

5. Bryan, J., Holcomb-McCoy, C., Moore-Thomas, C., \& DayVines, N. L. (2009). Who Sees the School Counselor for College Information? A National Study. Professional School Counseling, 12(4), 280-291. doi: 10.1177/2156759X0901200401

6. Carey, J., \& Dimmitt, C. (2012). School Counseling and Student Outcomes: Summary of Six Statewide Studies. Professional School Counseling, 16(2), 146-153. doi: 10.1177/ 2156759X 0001600204

7. Erickson, A., \& Abel, N. R. (2013). A High School Counselor's Leadership in Providing School-Wide Screenings for Depression and Enhancing Suicide Awareness. Professional School Counseling, 16(5), 283-289. doi: 10.1177/2156759X 1201600501

8. Goodman-Scott, E., Sink, C., Cholewa, B., Burgess, M. (2018). An ecological view of school counselor ratios and student academic outcomes: A national investigation. Journal of Counseling and Development, 96(10), 388-398. doi: 10.1002/ jcad.12221

9. Hurwitz, M., \& Howell, J. (2014). Estimating causal impacts of school counselors with regression discontinuity designs. Journal of Counseling \& Development, 92(3), 316-327. doi: 10.1002/ j.1556-6667.2014.00159.x

10. Cholewa, B., Burkhardt, C., Hull, M. (2015). Are School Counselors Impacting Underrepresented Students' Thinking about Postsecondary Education? A Nationally Representative Study Professional School Counseling, 19(1), 144-154. doi: 10.5330/1096-2409-19.1.144

11. Kayler, H., \& Sherman, J. (2009). At-risk ninth-grade students: A psychoeducational group approach to increase study skills and grade point averages. Professional School Counseling, 12(6), 434-439. doi: 10.1177/2156759X0901200608

12. Krell, M., \& Perusse, R. (2012). Providing College Readiness Counseling for Students with Autism Spectrum Disorders: A Delphi Study to Guide School Counselors.. Professional School Counseling, 16 (1), 29-39. doi: 10.1177/ 2156759X1201600104

13. Lapan, R., Poynton, T., Balkin, R., Jones L. (2019). ASCA National Model Implementation and Appropriate School Counselor Ratios Promote More Informed CollegeDecisionMaking. Research report. Retrieved from https://asca-prod. azurewebsites.net/asca/media/asca/Publications/EffectivenessAppRatios-ResearchReport.pdf

14. Lapan, R. T., Gysbers, N. C., Bragg, S., \& Pierce, M. E. (2012). Missouri Professional School Counselors: Ratios Matter, 
Especially in High-Poverty Schools. Professional School Counseling, 16(2), 108-116. doi: 10.1177/2156759X0001600207 15. Lapan, R. T., Whitcomb, S. A., \& Aleman, N. M. (2012). Connecticut Professional School Counselors: College and Career Counseling Services and Smaller Ratios Benefit Students. Professional School Counseling, 16(2), 117-124. doi: 10.1177/ 2156759X0001600206

16. Leon, A., Villares, E., Brigman, G., Webb, L, \& Peluso, P. (2011). Closing the gap in the success of Latin American / Latin American students: a school counseling response. Counseling Outcome Research and Evaluation, 2(1), 73-86. doi: 10.1177/ 2150137811400731

17. Mariani, M., Berger, C., Koerner, K., Sandlin, C. (2016). Operation Occupation: A College and Career Readiness Intervention for Elementary Students. Professional School Counseling, 20(1), 65-76. doi: 10.5330/1096-2409-20.1.65

18. McKenzie, K., Murray, K. R., Murray, A. L., \& Richelieu, M. (2015). The effectiveness of university counselling for students with academic issues. Counselling \& Psychotherapy Research, 15(4), 284-288. Retrieved from: https://onlinelibrary. wiley.com/ doi/pdf/10.1002/capr.12034

19. Militello, M., Carey, J., Dimmitt, C., Lee, V.\& Schweid, J. (2009). Identifying Exemplary School Counseling Practices inNationally Recognized High Schools. Journal od School Counseling, 7(13), 1-26. Retrieved from: http://www.jsc. montana.edu/articles/v7n13.pdf

20. Minksová, L. (2010). Vysokoškoláci - přehled hlavních sociologických výzkumů realizovaných v ČR. Data a výzkum SDA Info 2010, 4(1), 39-10. Retrieved from http://dav.soc. cas.cz/uploads/0cef0da1bacc35ea4353fd5d8eb52bb1bd9add7e_ DaV10_1_s39_60.pdf

21. Parzych, J., Donohue, P., Gaesser, A., Chiu, M. (2019). Measuring the Impact of School Counselor Ratios on Student Outcomes. Retrieved from https://www.schoolcounselor.org/ getmedia/5157ef82-d2e8-4b4d-8659-a957f14b7875/RatiosStudent-Outcomes-Research-Report.pdf

22. Pham, C., \& Keenan, T. (2011). Counseling and college matriculation: Does the availability of counselingaffectcollegegoing decisionsamonghighly qualified first-generation collegebound high school graduates? Journal of Applied Economics and Business Research, 1(1), 12-24. Dostupné z: http://www. aebrjournal.org/uploads/6/6/2/2/6622240/3_cp_tk_college.pdf 23. Slavík, M. (2012). Vysokoškolská pedagogika. Praha: Grada. 24. Steen, S., Liu, X., Shi, Q., Rose, J., Merino, G. (2018). Promoting School Adjustment for English-Language Learners Through Group Work. Professional School Counseling, 21(1), 1-10. doi: $10.1177 / 2156759 X 18777096$

25. Villares, E., Lemberger, M., Brigman, G., \& Webb, L. (2011). Student Success Skills: An evidence-based school counseling program grounded in humanistic theory. Journal of Humanistic Counseling, 50, 42-55. doi: 10.1002/j.2161-1939. 2011.tb00105.x

26. Watkinson, J. S., \& Hersi, A. A. (2014). School Counselors Supporting African Immigrant Students' Career Development: A Case Study. The Career Development Quarterly, 62(1), 44-55. doi: 10.1002/j.2161-0045.2014.00069.x

27. Whiston, S.C., Quinby, R.F. (2009). Review of school counselling outcome research. Psychology in the Schools. 46(3), 267-272. Retrieved from https://onlinelibrary.wiley.com/doi/pdf/ 10.1002/pits.20372

28. Wilkerson, K., Perusse, R., \& Hughes, A. (2013). Comprehensive School Counseling Programs and Student Achievement Outcomes: A Comparative Analysis of RAMP versus Non-RAMP Schools. Professional School Counseling, 16(3), 172-184. doi: 10.1177/2156759X1701600302

\section{Primary Paper Section: A}

\section{Secondary Paper Section: AM, AN}

